\section{Genome-wide analysis of 5-hydroxymethylcytosine distribution reveals its dual function in transcriptional regulation in mouse embryonic stem cells}

Hao Wu, ${ }^{1,2,7}$ Ana C. D'Alessio, ${ }^{3,4}$ Shinsuke Ito, ${ }^{3,4}$ Zhibin Wang, ${ }^{5}$ Kairong Cui, ${ }^{6}$ Keji Zhao, ${ }^{6}$ Yi Eve Sun, ${ }^{1,2}$ and Yi Zhang ${ }^{3,4,8}$

${ }^{1}$ Department of Molecular and Medical Pharmacology, David Geffen School of Medicine, University of California at Los Angeles, Los Angeles, California 90095, USA; ${ }^{2}$ Department of Psychiatry and Biobehavioral Sciences, Intellectual Development and Disabilities Research Center, Semel Institute of Neuroscience and Human Behavior, University of California at Los Angeles, Los Angeles, California 90095, USA; ${ }^{3}$ Howard Hughes Medical Institute, University of North Carolina, Chapel Hill, North Caroline 27599, USA; ${ }^{4}$ Department of Biochemistry and Biophysics, Lineberger Comprehensive Cancer Center, University of North Carolina, Chapel Hill, North Carolina 27599, USA; ${ }^{5}$ Laboratory of Human Environmental Epigenomes, Department of Environmental Health Sciences, Johns Hopkins Bloomberg School of Public Health, Baltimore, Maryland 21025, USA; ${ }^{6}$ Laboratory of Molecular Immunology, The National Heart, Lung, and Blood Institute, National Institutes of Health, Bethesda, Maryland 20892, USA

Recent studies have demonstrated that the Ten-eleven translocation (Tet) family proteins can enzymatically convert 5-methylcytosine $(5 \mathrm{mC})$ to 5 -hydroxymethylcytosine (5hmC). While $5 \mathrm{mC}$ has been studied extensively, little is known about the distribution and function of $5 \mathrm{hmC}$. Here we present a genome-wide profile of $5 \mathrm{hmC}$ in mouse embryonic stem (ES) cells. A combined analysis of global $5 \mathrm{hmC}$ distribution and gene expression profile in wild-type and Tet1-depleted ES cells suggests that $5 \mathrm{hmC}$ is enriched at both gene bodies of actively transcribed genes and extended promoter regions of Polycombrepressed developmental regulators. Thus, our study reveals the first genome-wide $5 \mathrm{hmC}$ distribution in pluripotent stem cells, and supports its dual function in regulating gene expression.

Supplemental material is available for this article.

Received January 25, 2011; revised version accepted February 22, 2011.

[Keywords: Tet1; 5-methylcytosine $(5 \mathrm{mC}) ;$ 5-hydroxymethylcytosine $(5 \mathrm{hmC})$; mouse embryonic stem cells; genome-wide $5 \mathrm{hmC}$ distribution Polycomb repression]

${ }^{7}$ Present address: Cardiovascular Research Center, Massachusetts General Hospital, 185 Cambridge St., Boston, MA 02114, USA, and Department of Stem Cell and Regenerative Biology, Harvard University, 7 Divinity Ave., Cambridge, MA 02138, USA.

${ }^{8}$ Corresponding author.

E-MAIL yi zhang@med.unc.edu; FAX (919) 966-4330.

Article is online at http://www.genesdev.org/cgi/doi/10.1101/gad.2036011.
Mammalian genomes are chemically modified by DNA cytosine methylation, an inheritable epigenetic mark that is implicated in many biological and pathological processes, including gene regulation, genomic imprinting, X-chromosome inactivation, suppression of transposable elements, and tumorigenesis (Cedar and Bergman 2009; Ooi et al. 2009). Genome-wide studies of mammalian DNA methylation have shown that 5-methylcytosine $(5 \mathrm{mC})$ is widely distributed across the genome in a nonrandom manner (Weber et al. 2007; Fouse et al. 2008; Meissner et al. 2008; Lister et al. 2009|. In conjunction with other epigenetic modifications, $5 \mathrm{mC}$ can regulate accessibility of the DNA to transcription factors and chromatin regulators, thereby contributing to gene regulation and cellular differentiation.

Recent studies have uncovered 5-hydroxymethylcytosine $(5 \mathrm{hmC})$ as the sixth base of the genome, and that the Ten-eleven translocation (Tet) family proteins is responsible for the generation of $5 \mathrm{hmC}$ from $5 \mathrm{mC}$ in mammalian cells (Kriaucionis and Heintz 2009; Tahiliani et al. 2009; Ito et al. 2010). This new discovery raises the possibility that $5 \mathrm{hmC}$ may function as another epigenetic mark by altering chromatin structure or contributing to the recruitment or exclusion of other DNA-binding proteins that affect transcription. Recent reports have shown that $5 \mathrm{hmC}$ is relatively enriched in several cell types, including mouse embryonic stem (ES) cells and certain neuronal cells (Kriaucionis and Heintz 2009; Tahiliani et al. 2009; Globisch et al. 2010; Szwagierczak et al. 2010). Expression and functional analysis have further demonstrated that Tet1, the founding member of the Tet family, is highly expressed in mouse ES cells, and depletion of Tet1 results in impairment of ES cell self-renewal and maintenance (Ito et al. 2010). Consistent with the essential role of Tet 1 in ES cells, we showed recently that Tet1 occupies regulatory regions of both pluripotency-related genes and Polycomb group (PcG) protein-repressed developmental regulators (Wu et al. 2011). However, little is known about the genomic distribution of $5 \mathrm{hmC}$, dependence of $5 \mathrm{hmC}$ on Tet1 occupancy, and the regulatory function of $5 \mathrm{hmC}$ on transcription. Here we report the first genome-wide map of $5 \mathrm{hmC}$ occupancy in mouse ES cells. The comparison of $5 \mathrm{hmC}$ distribution with other epigenetic marks and global expression profile provides evidence for a role of $5 \mathrm{hmC}$ in both transcriptional activation and repression.

\section{Results and Discussion}

\section{Genome-wide distribution of $5 \mathrm{hm} C$ in mouse ES cells}

To test the specificity of $5 \mathrm{hmC}$ antibodies in immunoprecipitating unmethylated, methylated, and hydroxymethylated synthetic DNA, we optimized the amount of input DNA and found that affinity-purified polyclonal antibodies (Active Motif) for $5 \mathrm{hmC}$ specifically immunoprecipitated $5 \mathrm{hmC}$-containing, but not $5 \mathrm{mC}$ - or C-containing, DNA under denaturing conditions (Supplemental Fig. S1A). We then tested the ability of both rabbit polyclonal (Active Motif) and rat monoclonal (Diagenode) antibodies in immunoprecipitation of genomic DNA at three Tet1bound targets (Nanog, Tcl1, and Sox17) determined by 
Tet1 chromatin immunoprecipitation (ChIP) sequencing (ChIP-seq) (Wu et al. 2011). Quantitative PCR (qPCR) analysis indicated that both antibodies could readily immunoprecipitate 5hmC-modified genomic DNA, and $5 \mathrm{hmC}$ polyclonal antibodies showed slightly higher immunoprecipitation efficiency as compared with the monoclonal antibody (Supplemental Fig. S1B,C).

To determine global distribution of $5 \mathrm{hmC}$, we further tested $5 \mathrm{hmC}$ antibody-based immunoprecipitation combined with chromosome-wide tiling microarrays (Supplemental Fig. S2A). We found that both antibodies could consistently detect peaks of $5 \mathrm{hmC}$ at defined genomic regions, and that the $5 \mathrm{hmC}$ profile was different from that of $5 \mathrm{mC}$ at both gene and probe levels (Supplemental Fig. S2A-C), suggesting that the $5 \mathrm{hmC}$ antibody is specific. Since the majority of Tet1-binding sites in mouse ES cells are within nonrepetitive, gene-rich genomic regions $(\mathrm{Wu}$ et al. 2011), we mapped $5 \mathrm{hmC}$ distribution using wholegenome tiling microarrays that covered the entire nonrepetitive portion of the mouse genome. A total of 91,913 genomic regions enriched with $5 \mathrm{hmC}$ were identified with high confidence (Supplemental Table S1). Nearly $60 \%$ of $5 \mathrm{hmC}$ peaks were found to be within gene bodies of annotated RefSeq genes (Fig. 1A), suggesting that $5 \mathrm{hmC}$ is also preferentially associated with gene-rich regions of the genome (Supplemental Fig. 2A). We note that a recent study profiling the $5 \mathrm{hmC}$ distribution in mouse cerebellum using a different method has come to a similar conclusion (Song et al. 2011). Further analysis showed that most $5 \mathrm{hmC}$-enriched regions were associated with moderate CpG density (Fig. 1B). Thus, 5hmC

A

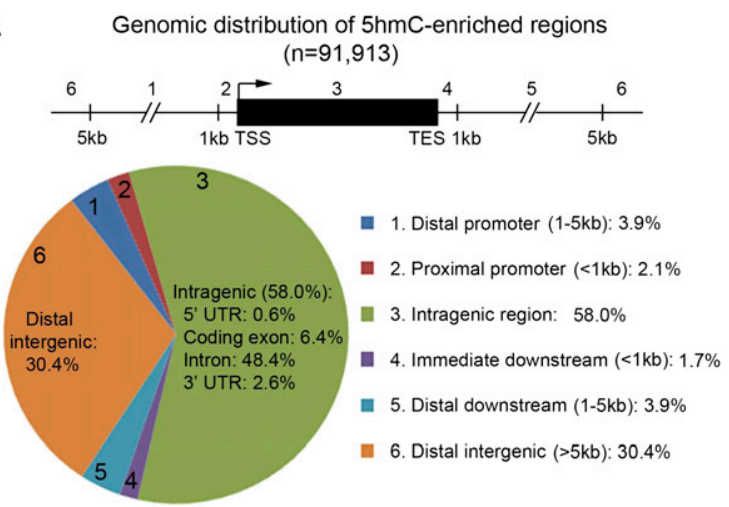

B $5 \mathrm{hmC}$ enriched regions $(\mathrm{n}=91,913)$

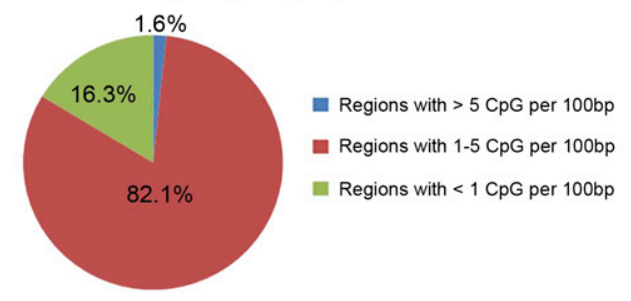

Figure 1. Genomic distribution of $5 \mathrm{hmC}$ in mouse ES cells. $(A)$ Genomic distribution of $5 \mathrm{hmC}$-enriched regions $\left(\left[-\log _{10}\right.\right.$ peak $P$-value] $>2.3$ ) relative to University of California at San Diego RefSeq genes (NCBI build 36). The genome-wide $5 \mathrm{hmC}$ occupancy was determined by whole-genome tiling microarray analysis. $(B)$ Proportion of $5 \mathrm{hmC}$-enriched regions with different $\mathrm{CpG}$ densities. Note that $5 \mathrm{hmC}$ is enriched at genomic regions with moderatedensity CpG dinucleotides. antibody-based DNA immunoprecipitation (hMeDIP) provides a simple and specific tool to investigate the genomic distribution and function of $5 \mathrm{hmC}$ in mammalian cells.

\section{Tet1 is required for maintaining $5 \mathrm{hmC}$ levels at defined genomic regions}

We next mapped the $5 \mathrm{hmC}$ peaks to all annotated RefSeq genes in the mouse genome. We found that $5 \mathrm{hmC}$ was preferentially enriched in Tet1-bound genes as compared with Tet1-unbound genes (Fig. 2A), consistent with the known enzymatic activity of Tet1. Further analyses of $5 \mathrm{hmC}$ peaks within regions flanking transcriptional start sites (TSSs) of annotated genes indicated that $5 \mathrm{hmC}$ levels were high in genomic regions flanking CpG-rich proximal promoters and within Tet1-bound CpG-poor promoters (Supplemental Fig. S3A). Mapping of $5 \mathrm{hmC}$ peaks to Tet1-bound sites also supported the observation that $5 \mathrm{hmC}$ tended to be more enriched in genomic regions with medium levels of CpG density (Supplemental Fig. S3B,C). In fact, $5 \mathrm{hmC}$ appeared to be excluded from Tet1-binding sites with high CpG density (Supplemental Fig. S3C). The lack of high levels of $5 \mathrm{hmC}$ within these CpG-rich regions may possibly be explained by two nonmutually exclusive mechanisms: (1) Tet1 is capable of rapidly hydrolyzing $5 \mathrm{mC}$ into $5 \mathrm{hmC}$, which in turn is converted to unmethylated cytosine by yet-to-be-identified downstream enzymes within $\mathrm{CpG}$-rich regions. (2) High levels of trimethylated $\mathrm{H} 3 \mathrm{~K} 4$ (H3K4me3) within CpG-rich regions prevent efficient binding of the de novo DNA methyltransferase complex Dnmt3a2/Dnmt3b/ Dnmt31 in mouse ES cells to these DNA sequences /Ooi et al. 2007), and thus inhibit accumulation of $5 \mathrm{mC}$ (Supplemental Fig. S3C).

To further investigate the dependence of $5 \mathrm{hmC}$ distribution on Tet1 occupancy, we performed lentivirusmediated knockdown of Tet1 in mouse ES cells (Ito et al. 2010). The results shown in Figure 2B demonstrate that knockdown of Tet 1 resulted in reduced $5 \mathrm{hmC}$ levels at Tet1 regions throughout the genome that include Tet1bound promoters, gene bodies, and intergenic regions. Many Tet1-binding sites, particularly those at CpG-rich proximal promoters, did not show a decrease in $5 \mathrm{hmC}$ level in the absence of Tet1 proteins (Fig. 2B,C; Supplemental Fig. S4A,B). This is likely due to a lack of $5 \mathrm{hmC}$ enrichment at these sites in wild-type mouse ES cells (Fig. 2C; Supplemental Fig. S3C). However, an increase in $5 \mathrm{mC}$ levels was still frequently observed within both promoter and nonpromoter Tet1-binding sites (Fig. 2B-D; Supplemental Fig. S4A), indicating that Tet1 has a role in maintaining a DNA hypomethylated state at these sites. Taken together, these results indicate that Tet 1 is required for establishing a defined genomic pattern of $5 \mathrm{hmC}$, and also for initiating an enzymatic cascade to maintain CpG-rich gene promoters in a DNA hypomethylated state.

\section{$5 \mathrm{hmC}$ is enriched in both Tet1-activated and Tet1-repressed genes}

Previous genome-wide analyses have shown that distribution of DNA methylation in the genome may also be regulated by histone modifications (Ooi et al. 2007; Schlesinger et al. 2007; Mohn et al. 2008). For example, $\mathrm{H} 3 \mathrm{~K} 4 \mathrm{me} 3$ at proximal promoters generally regulates 
A

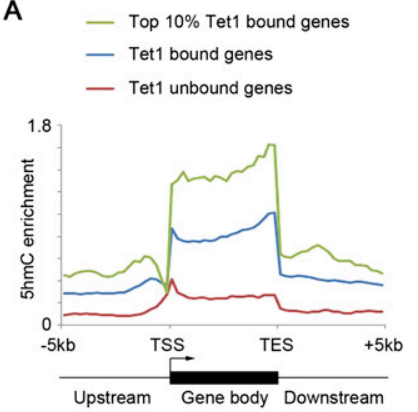

C

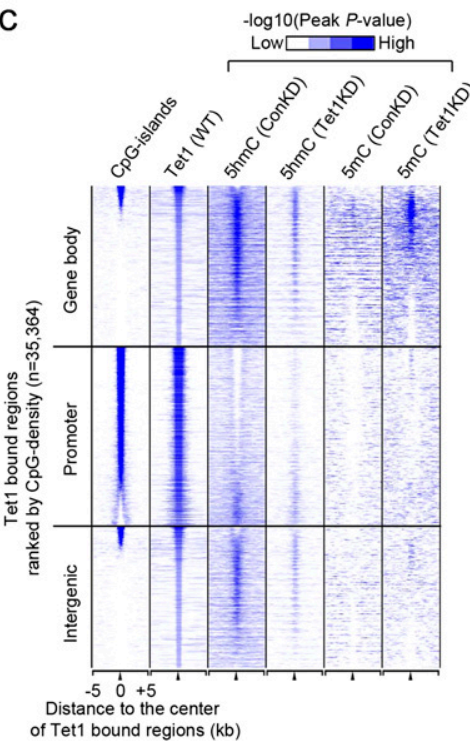

B

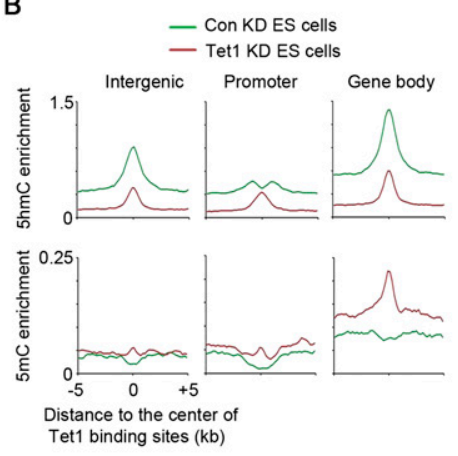

D

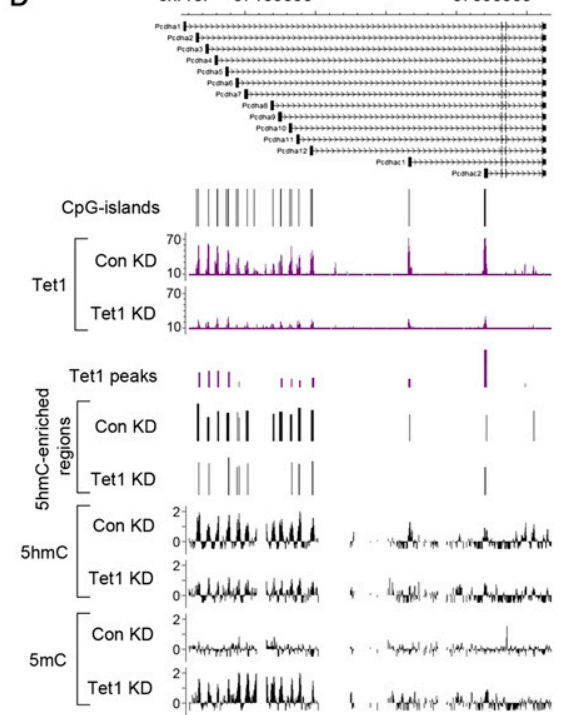

Figure 2. Tet 1 is required for maintaining $5 \mathrm{hmC}$ levels at defined genomic regions in ES cells. (A) Distribution of $5 \mathrm{hmC}$ relative to all annotated genes in ES cells. Averaged $5 \mathrm{hmC}$ enrichment (measured by $-\log _{10}$ peak $P$-value) in 200-base-pair (bp) bins upstream of/downstream from gene bodies or at $5 \%$ intervals within the gene body is shown along the transcription units from $5 \mathrm{~kb}$ upstream of TSSs to $5 \mathrm{~kb}$ downstream from the transcriptional end sites (TESs). Note that $5 \mathrm{hmC}$ levels are generally enriched in Tet1-bound genes as compared with Tetl-unbound genes. (B) Changes in $5 \mathrm{hmC}$ and $5 \mathrm{mC}$ enrichment (measured by $-\log _{10}$ peak $P$-value) in response to Tet 1 knockdown are shown for Tet1-bound regions associated with different genomic features (gene body, intergenic region, and promoter [2 kb flanking TSSs]). (C) Heat map representation of CpG islands and occupancy of Tet $1,5 \mathrm{mC}$, and $5 \mathrm{hmC}$ in mouse ES cells at all Tet1enriched regions ( $5 \mathrm{~kb}$ flanking the center of Tet 1 peaks). The heat map is rank-ordered by CpG density of genomic regions within 500 bp flanking the center of Tetl peaks. The enrichment of $5 \mathrm{hmC}$ and $5 \mathrm{mC}$ was determined by whole-genome tiling microarrays. Tetlbound regions at gene bodies, promoters, and intergenic regions are shown separately. The enrichment of Tet1 binding was determined previously by ChIP-seq analyses (Wu et al. 2011). All average binding was measured by $-\log _{10}$ (peak $P$-values) in 200 -bp bins and are shown by color scale. The following color scales (white, no enrichment; blue, high enrichment) are used for $5 \mathrm{hmC}, 5 \mathrm{mC}$, and Tetl, respectively: $[0,2],[0,0.5]$, and $[0,50]$. The presence of CpG islands is displayed in color (blue, present; white, absent). (D) Tet1 occupancy and changes in $5 \mathrm{hmC} / 5 \mathrm{mC}$ levels are shown for a group of representative Tet 1 targets (Pcdha gene cluster on chr18) in control (Con) and Tetl knockdown (Tetl KD) ES cells. Tetl ChIP-seq data in control knockdown (Con KD) and Tet1 knockdown (Tet1 KD) are shown in read counts, with the $Y$-axis floor set to 0.2 read per million reads. $5 \mathrm{hmC}$ and $5 \mathrm{mC}$ levels are shown as $\log _{2}$ ratios of immunoprecipitation/input (IP/input).

DNA methylation levels in a negative fashion (Weber et al. 2007; Meissner et al. 2008), whereas H3K36me3 within actively transcribed gene bodies is positively correlated with the presence of high levels of DNA methylation (Ball et al. 2009). To further investigate the relationship between Tet1, $5 \mathrm{hmC}$, and major histone modifications at Tet1-bound genes, we cross-referenced the $5 \mathrm{hmC}$ profile with published genomewide occupancy of major histone modifications. As Tetl can bind to both actively transcribed genes and Polycomb repression complex 2 (PRC2)-repressed developmental regulators (positive for Ezh2 and H3K27me3) (Wu et al. 2011), we analyzed these two groups of Tet1-bound genes separately (Fig. 3A). This analysis revealed that $5 \mathrm{hmC}$ was relatively more enriched at intragenic regions (Fig. 3B,C), particularly at the 3 ' end of the gene body for actively transcribed Tet1-only targets (e.g., Rest in Fig. $3 \mathrm{C})$, similar to the transcription elongation mark H3K36me3 (Mikkelsen et al. 2007). In contrast, enrichment of $5 \mathrm{hmC}$ was more prominent at extended promoter regionsincluding both upstream of and downstream from TSSs (Fig. 3B,C) - of Tet1/PRC2cobound targets (e.g., Lhx2 in Fig. 3C). Thus, $5 \mathrm{hmC}$ enrichment at Tet1-bound genes may contribute to maintenance of both the transcriptionally active and inactive chromatin states by functionally interacting with distinct histone modifications and their associated proteins.

Relationship between $5 \mathrm{hmC}$ distribution and chromatin occupancy of pluripotency-related transcription factors and other genomic features

The fact that DNA methylation can affect the binding of many DNA-binding proteins to their target sequences raises the possibility that $5 \mathrm{hmC}$ may also be involved in regulating the protein-DNA interactions. To investigate this potential relationship in mouse ES cells, we mapped $5 \mathrm{hmC}$ microarray signals to previously determined binding sites of a set of proteins important for pluripotency (e.g., Nanog, Sox2, and Oct4) (Chen et al. 2008). In contrast to a general depletion of $5 \mathrm{mC}$ at DNA-protein interaction sites, we observed a relative enrichment of $5 \mathrm{hmC}$ toward the site of most DNA-binding proteins (Supplemental Fig. S5). Previous analysis of DNA methylation in human ES cells using whole-genome bisulfite sequencing suggests that $5 \mathrm{mC}$ in a non-CpG context, but not CpG DNA methylation, is greatly depleted from binding sites of transcription factors related to pluripotency (Lister et al. 2009). Since bisulfite treatment cannot discriminate $5 \mathrm{mC}$ from 5hmC (Huang et al. 2010; Jin et al. 2010), bisulfite sequencing may overestimate the $5 \mathrm{mC}$ levels at these binding sites. Indeed, specific antibody-based immunoprecipitation analysis of $5 \mathrm{mC}$ and $5 \mathrm{hmC}$ in mouse ES cells indicated that $5 \mathrm{mC}$ was generally depleted from DNA-protein interaction sites, whereas $5 \mathrm{hmC}$ was relatively enriched at these sites (Supplemental Fig. S5).

We next analyzed a set of genomic features defined by histone modifications or sequence-specific DNA-binding 


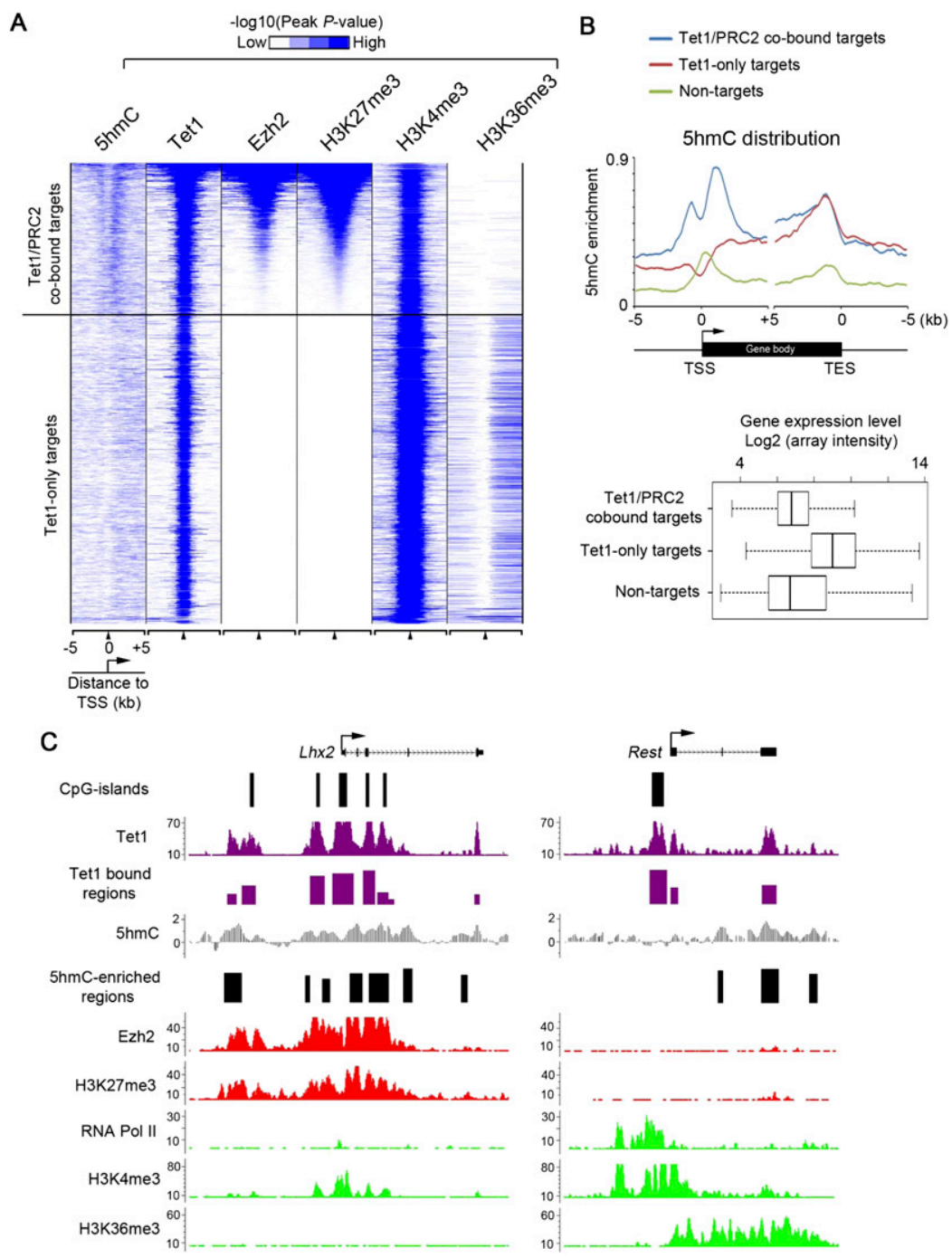

Figure 3. $5 \mathrm{hmC}$ is enriched in both repressed (bivalent, Tet1/PRC2-cobound) and actively transcribed (Tet1-only) genes. $(A)$ Heat map representation of genomic regions with enriched $5 \mathrm{hmC}$, binding profile of Tet 1 and Ezh2, and major histone modifications (H3K4me3, H3K27me3, and H3K36me3) (Mikkelsen et al. 2007) in mouse ES cells at all Tetl target genes (5 kb flanking TSSs). The heat map is rank-ordered from genes with the highest $\mathrm{H} 3 \mathrm{~K} 27 \mathrm{me} 3$ enrichment to no $\mathrm{H} 3 \mathrm{~K} 27 \mathrm{me} 3$ within 5 - $\mathrm{kb}$ genomic regions flanking TSSs. The enrichment of $5 \mathrm{hmC}$ and $5 \mathrm{mC}$ was determined by whole-genome tiling microarrays. The enrichment of Tet1, H3K4me3, H3K27me3, and H3K36me3 binding was determined previously by ChIP-seq analyses (Mikkelsen et al. 2007; Wu et al. 2011). All average binding was measured by $-\log _{10}$ (peak $P$-values) in 200-bp bins and is shown by color scale. The following color scales (white, no enrichment; blue, high enrichment) are used for $5 \mathrm{hmC} / 5 \mathrm{mC}$, Tet1/H3K27me3/H3K36me3, and H3K4me3, respectively: $[0,2],[0,50]$, and $[0,100]$. The presence of $\mathrm{CpG}$ islands is displayed in color (blue, present; white, absent). $(B)$ Average distribution profiles of $5 \mathrm{hmC}$ enrichment are shown for Tet1/PRC2-cobound targets, Tet1-only targets, and nontargets. Averaged expression levels of these three groups of genes are shown in the bottom panels (measured by $\log _{2}$ values of expression microarray signals). (C) Shown are profiles of Tet1 (Wu et al. 2011), 5hmC, Ezh2 (Ku et al. 2008), RNA polymerase II (Seila et al. 2008), and major histone modification (Mikkelsen et al. 2007) occupancy at two representative Tetl targets: a Tet1/PRC2cobound target (Lhx2), and a Tet1-only target (Rest promoter). ChIP-seq data in mouse ES cells are shown in read counts, with the $Y$-axis floor set to 0.2 read per million reads.

proteins, including $\mathrm{H} 3 \mathrm{~K} 4 \mathrm{me} 3$-enriched promoter regions, methylated H3K4 (H3K4me1)-enriched enhancers, Ctcfmarked insulators, and H3K36me3-enriched transcribed intragenic regions (Mikkelsen et al. 2007; Chen et al. 2008; Meissner et al. 2008). Except for H3K36me3enriched regions, $5 \mathrm{mC}$ was, in general, depleted from these genomic features (Supplemental Fig. S5), consistent with the notion that DNA methylation negatively regulates most DNA-protein interactions. In contrast, average signal profiles of $5 \mathrm{hmC}$ showed a relative enrichment at promoters, enhancers, transcribed regions, and insulators (Supplemental Fig. S5). Notably, the general enrichment of $5 \mathrm{hmC}$ at $\mathrm{H} 3 \mathrm{~K} 4 \mathrm{me} 3$ peaks indicates that the absence of $5 \mathrm{hmC}$ at a subset of CpG-rich, H3K4me3-enriched proximal promoters is probably due to the existence of additional regulatory factors of Tet1 activity or proteins capable of rapidly converting 5 hmC into unmethylated cytosine at these sites. Furthermore, the observed enrichment of $5 \mathrm{hmC}$ and concomitant depletion of $5 \mathrm{mC}$ at enhancer or insulator sequences may therefore contribute to maintaining a more accessible chromatin structure for binding of enhancer proteins (e.g., p300) and Ctcf to these sites. Enrichment of both $5 \mathrm{hmC}$ and $5 \mathrm{mC}$ at actively transcribed regions marked by high levels of H3K36me3 suggests a transcriptional link between these two marks (Supplemental Fig. S5).

\section{$5 \mathrm{hm} C$ has different distribution profiles at active and repressed genes}

To investigate a potential role of $5 \mathrm{hmC}$ in transcriptional regulation, we examined the relationship between $5 \mathrm{hmC}$ distribution and the global gene expression profile. This analysis showed that $5 \mathrm{hmC}$ was relatively enriched within intragenic regions of genes transcribed at high and medium levels (Fig. 4A, blue and red; Supplemental Fig. S6, blue and red), as well as promoter regions of transcriptionally inactive genes (Fig. 4A, green; Supplemental Fig. S6, green). Further analysis of $5 \mathrm{hmC}$ distribution on Tet1bound genes ranked by their expression levels also supported a potential role of $5 \mathrm{hmC}$ in both transcriptional activation and repression (Fig. 4B). Interestingly, $5 \mathrm{hmC}$ was enriched at promoters of both Tet1/PRC2-cobound (Supplemental Fig. S7, blue) and Tet1-only targets that were expressed at low levels (Supplemental Fig. S7, purple) in mouse ES cells, suggesting that promoter $5 \mathrm{hmC}$ may function as a general repressive mark (Supplemental Fig. S7). To investigate further how $5 \mathrm{hmC}$ distribution may contribute to Tet1-dependent gene expression, we compared the $5 \mathrm{hmC}$ profiles between control and Tet1-depleted ES cells on Tet1-repressed and Tet1-activated targets. We found that $5 \mathrm{hmC}$ levels were decreased at both groups of Tetl targets (Supplemental Fig. S8). A decrease in $5 \mathrm{hmC}$ was more pronounced at promoter regions and the $5^{\prime}$ end of intragenic regions on Tet1-repressed targets, whereas a depletion of intragenic $5 \mathrm{hmC}$ was evident for Tetl-activated targets. Taken together, these results indicate that, similar to $5 \mathrm{mC}, 5 \mathrm{hmC}$ may play a complex role in 
- Medium (40-60\%)

- Low $(80-100 \%)$
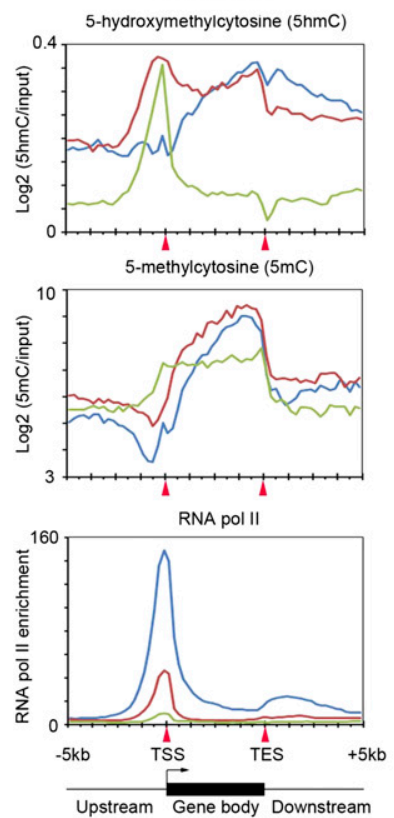

B
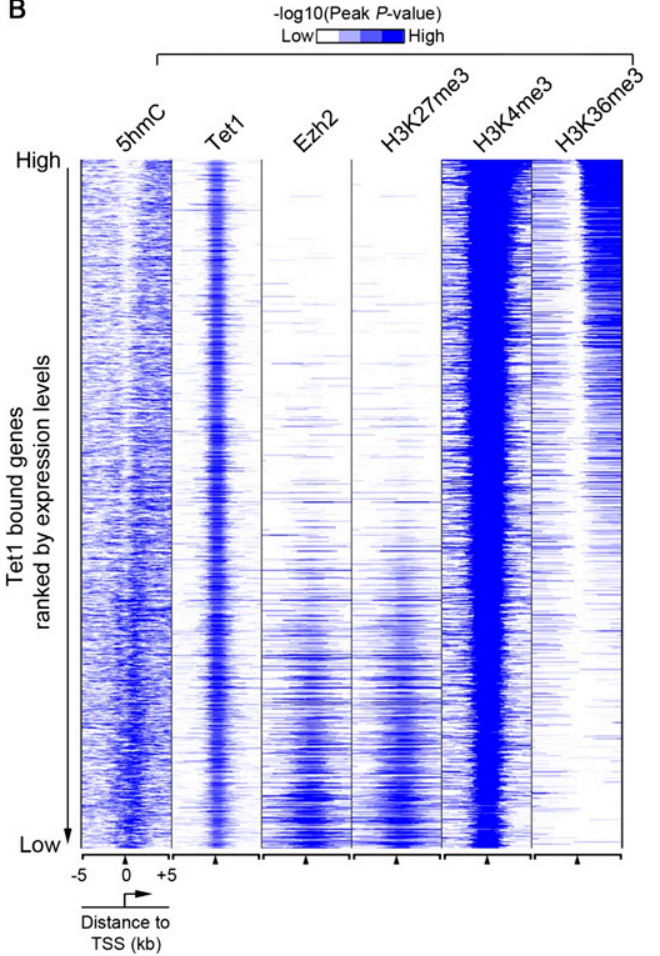

Figure 4. Relationship between $5 \mathrm{hmC}$ enrichment and gene expression in mouse ES cells. (A) Distribution of $5 \mathrm{hmC}, 5 \mathrm{mC}$, and RNA polymerase II at genes expressed at different levels in ES cells. Enrichment of $5 \mathrm{hmC}$ and $5 \mathrm{mC}$ was measured by raw $\log _{2}$ ratios of immunoprecipitation/input (IP/input) and MEDME-corrected values of $\log _{2}$ ratios, respectively. $(B)$ Heat map representation of genomic regions with enriched $5 \mathrm{hmC}$, binding profile of Tet1 and Ezh2, and major histone modifications in mouse ES cells at all Tet1 target genes ( $5 \mathrm{~kb}$ flanking TSSs). The heat map is rank-ordered by gene expression levels of Tet1-bound genes. All average binding was measured by $-\log _{10}$ (peak $P$-values) in 200-bp bins and is shown by color scale. The following color scales (white, no enrichemnt; blue, high enrichment) are used for $5 \mathrm{hmC}$, Tet1/Ezh2/H3K27me3/ H3K36me3, and H3K4me3, respectively: $[0,2],[0,50]$, and $[0,100]$.

transcriptional regulation, depending on its location $(\mathrm{Wu}$ et al. 2010). Our analysis of $5 \mathrm{hmC}$ distribution in mouse ES cells suggests that promoter and gene body $5 \mathrm{hmC}$ may preferentially contribute to gene repression and activation, respectively.

In summary, our studies have presented a genome-wide map of $5 \mathrm{hmC}$ in mouse ES cells. Systematic comparison of $5 \mathrm{hmC}$ distribution, Tet 1 occupancy, and major histone modifications indicate that $5 \mathrm{hmC}$ may be involved in establishing and maintaining chromatin structure for both actively transcribed genes and PcG-repressed developmental regulators. We also provide initial evidence indicating that $5 \mathrm{hmC}$ may contribute to both transcriptional activation and repression in a context-dependent manner. Collectively, these results and the demonstration of a simple antibody-based approach in genome-wide $5 \mathrm{hmC}$ mapping have set the stage for further understanding the functions of Tet family proteins and $5 \mathrm{hmC}$ in development and disease.

\section{Materials and methods}

\section{Genome-wide and locus-specific 5hmC analysis (hMeDIP)}

To immunoprecipitate $5 \mathrm{hmC}$, genomic DNA was sequentially digested with proteinase $\mathrm{K}$ and RNase $\mathrm{A}$ and purified by phenol-chloroform extraction. Purified genomic DNA was sonicated to 200-1000 base pairs (bp) and heat-denatured $\left(10 \mathrm{~min}, 95^{\circ} \mathrm{C}\right)$. An aliquot of sonicated genomic DNA was saved as input. Five micrograms of fragmented genomic DNA was immunoprecipitated with $5 \mu \mathrm{g}$ of rat $5 \mathrm{hmC} \mathrm{Ab}$ (Diagenode, catalog no. MAb-633HMC) or rabbit $5 \mathrm{hmC} \mathrm{Ab}$ (Active Motif, cata$\log$ no. 39791 ) overnight at $4^{\circ} \mathrm{C}$ in a final volume of 500 $\mu \mathrm{L}$ of immunoprecipitation buffer $(10 \mathrm{mM}$ sodium phosphate at $\mathrm{pH} 7.0,140 \mathrm{mM} \mathrm{NaCl}, 0.05 \%$ Triton $\mathrm{X}-100)$. The DNA-antibody mixture was incubated with $30 \mu \mathrm{L}$ of protein G Dynabeads (Invitrogen) for $2 \mathrm{~h}$ at $4^{\circ} \mathrm{C}$ and washed three times with $1 \mathrm{~mL}$ of immunoprecipitation buffer. The beads were then treated with proteinase $\mathrm{K}$ for at least $3 \mathrm{~h}$ at $55^{\circ} \mathrm{C}$, and the methylated DNA was purified by phenol-chloroform extraction followed by ethanol precipitation. For whole-genome DNA tiling microarray analysis, immunoprecipitated 5hmC-containing DNA from control or Tet1-depleted ES cells was cohybridized with input DNA to mouse wholegenome tiling microarrays (NimbleGen). Locus-specific hMeDIP-qPCR was performed similarly using nondenatured genomic DNA, and immunoprecipitated DNA was analyzed on an ABI 7300 system (Applied Biosystems) using SYBR Green (Invitrogen). Primer sequences are listed in Supplemental Table S2.

To evaluate the immunoprecipitation efficiency of 5 hmC antibodies (Active Motif) for synthetic DNA (949 bp; Zimo Research), 25 pg of unmethylated, methylated, or hydroxymethylated DNA was diluted in 480 $\mu \mathrm{L}$ of $1 \times$ TE buffer. DNA was heat-denatured for $10 \mathrm{~min}$ at $95^{\circ} \mathrm{C}$, and chilled for $5 \mathrm{~min}$ on ice. $5 \mathrm{hmC}$ immunoprecipitation was performed as described above. qPCR was carried out with primers $\mathrm{H} / \mathrm{me}-1$-F (AGGTGGAGG AAGGTGATGTC) and H/me-1-R (ATAAACCGAACC GCTACACC).

\section{Whole-genome tiling microarray analysis}

For whole-genome DNA tiling microarray analysis of $5 \mathrm{hmC}$ distribution, immunoprecipitated and input DNA was prepared from both control and Tet1-depleted ES cells and amplified using a whole-genome amplification kit (Sigma). Probe labeling, amplification, hydridization, data extraction, and analysis were performed as described previously (Wu et al. 2011).

For identification of probes associated with significant levels of $5 \mathrm{hmC}$ a nonparametric one-sided Kolmogorov-Smirno (KS) test was used. Briefly, from the scaled $\log _{2}$ ratio data, a fixed-length window (750 bp) was placed around each consecutive probe, and the one-sided KS test was applied to determine whether the probes were drawn from a significantly more positive distribution of intensity log ratios than those in the rest of the array. The resulting score for each probe was the $\left[-\log _{10} P\right.$-value $]$ from the windowed KS test around that probe. Peak data files were generated from the $P$-value data files using NimbleScan version 2.5. Peaks within $500 \mathrm{bp}$ of each other were merged. For calculating the absolute $5 \mathrm{mC}$ levels in control knockdown and Tet1 knoockdown ES cells, the MEDME program (Pelizzola et al. 2008) was used to correct the nonlinear relationship between microarray signals and genomic $\mathrm{CpG}$ density. To visualize $5 \mathrm{mC}$ and $5 \mathrm{hmC}$ distributions in the Cisgenome browser (Ji et al. 2008), probe-level smoothing ( $\log _{2}$ ratios of probes within $1 \mathrm{~kb}$ are averaged) was performed for each probe. To calculate the peak distribution, averaged $5 \mathrm{hmC}$ or $5 \mathrm{mC}$ enrichment (measured by $\left[-\log _{10}\right.$ peak $P$-value]) was binned to 200 -bp intervals within genomic regions $5 \mathrm{~kb}$ upstream of and downstream from TSSs or transcriptional end sites (TESs) of annotated RefSeq genes. Heat maps were generated and visualized using Cluster 3 and Java Treeview, respectively. $5 \mathrm{mC}$ and $5 \mathrm{hmC}$ whole-genome tiling microarray data have been deposited in the Gene Expression Omnibus (http://www.ncbi.nlm.nih.gov/geo) under accession number GSE26833 (Wu et al. 2011) and GSE27613, respectively.

\section{Constructs and antibodies}

All of the constructs and antibodies used in this study were described previously (Ito et al. 2010; Wu et al. 2011). 


\section{ChIP-seq, gene expression profiling, and data analysis}

ChIP-seq experiments and data analysis for Tet1 were described previously (Wu et al. 2011). ChIP-seq data sets of H3K4me3, H3K27me3, H3K36me3 (Mikkelsen et al. 2007), Ezh2 (Ku et al. 2008), and RNA polymerase II (Seila et al. 2008) were obtained from previous publications and reanalyzed in MACS using identical parameters (except statistical cutoff was set to $P$-value $<10^{-5}$ ). ChIP-seq sequencing read counts for each ChIP-seq experiments were binned into 400-bp windows at 100-bp steps along the genome and visualized in the Cisgenome browser (Ji et al. 2008). To assign ChIP-seq enriched regions to genes, RefSeq genes were downloaded from the UCSC Table Browser (May 2010). For all data sets, genes with enriched regions within $5 \mathrm{~kb}$ of their TSSs were called bound. Gene expression profiling analysis of control and Tet1-depleted mouse ES cells was carried out using the Affymetrix GeneChip Mouse Genome 4302.0 array. Tetl ChIP-seq and gene expression microarray data have been deposited in the Gene Expression Omnibus under accession number GSE26833 (Wu et al. 2011).

\section{Mouse ES cell culture, Tet knockdown, and qPCR}

Mouse E14Tg2A ES cells were cultured in feeder-free conditions (Ito et al. 2010). Control and Tetl knockdown cell preparation and qPCR verification were described previously (Wu et al. 2011).

\section{Acknowledgments}

We thank Brian Abraham and Iouri Chepelev for help with data transfer, Jinzhao Wang for FACS sorting, and Susan Wu for critical reading of the manuscript. This work was supported by NIH grant GM68804 (to Y.Z.), and support to the Division of Intramural Research Program of National Heart, Lung, and Blood Institute from the NIH (to K.Z). S.I. is a research fellow of the Japan Society for the Promotion of Science. Y.Z. is an Investigator of the Howard Hughes Medical Institute.

\section{References}

Ball MP, Li JB, Gao Y, Lee JH, LeProust EM, Park IH, Xie B, Daley GQ, Church GM. 2009. Targeted and genome-scale strategies reveal genebody methylation signatures in human cells. Nat Biotechnol 27:361-368.

Cedar H, Bergman Y. 2009. Linking DNA methylation and histone modification: patterns and paradigms. Nat Rev Genet 10: 295-304.

Chen X, Xu H, Yuan P, Fang F, Huss M, Vega VB, Wong E, Orlov YL, Zhang W, Jiang $\mathrm{J}$, et al. 2008. Integration of external signaling pathways with the core transcriptional network in embryonic stem cells. Cell 133: 1106-1117.

Fouse SD, Shen Y, Pellegrini M, Cole S, Meissner A, Van Neste L, Jaenisch R, Fan G. 2008. Promoter CpG methylation contributes to ES cell gene regulation in parallel with Oct4/Nanog, PcG complex, and histone H3 K4/K27 trimethylation. Cell Stem Cell 2: 160-169.

Globisch D, Munzel M, Muller M, Michalakis S, Wagner M, Koch S, Bruckl T, Biel M, Carell T. 2010. Tissue distribution of 5-hydroxymethylcytosine and search for active demethylation intermediates. PLOS ONE 5: e15367. doi: 10.1371/journal.pone.0015367.

Huang Y, Pastor WA, Shen Y, Tahiliani M, Liu DR, Rao A. 2010. The behaviour of 5-hydroxymethylcytosine in bisulfite sequencing. PLOS ONE 5: e8888. doi: 10.1317/journal.pone.0008888.

Ito S, D'Alessio AC, Taranova OV, Hong K, Sowers LC, Zhang Y. 2010. Role of Tet proteins in $5 \mathrm{mC}$ to $5 \mathrm{hmC}$ conversion, ES-cell self-renewal and inner cell mass specification. Nature 466: 1129-1133.

Ji H, Jiang H, Ma W, Johnson DS, Myers RM, Wong WH. 2008. An integrated software system for analyzing ChIP-chip and ChIP-seq data. Nat Biotechnol 26: 1293-1300.

Jin SG, Kadam S, Pfeifer GP. 2010. Examination of the specificity of DNA methylation profiling techniques towards 5-methylcytosine and 5-hydroxymethylcytosine. Nucleic Acids Res 38: e125. doi: 10.1093/ nar/gkq223.

Kriaucionis S, Heintz N. 2009. The nuclear DNA base 5-hydroxymethylcytosine is present in Purkinje neurons and the brain. Science 324: 929-930.

Ku M, Koche RP, Rheinbay E, Mendenhall EM, Endoh M, Mikkelsen TS, Presser A, Nusbaum C, Xie X, Chi AS, et al. 2008. Genomewide analysis of $\mathrm{PRC} 1$ and PRC2 occupancy identifies two classes of bivalent domains. PLoS Genet 4: e1000242. doi: 10.1371/journal.pgen.1000242.
Lister R, Pelizzola M, Dowen RH, Hawkins RD, Hon G, Tonti-Filippini J, Nery JR, Lee L, Ye Z, Ngo QM, et al. 2009. Human DNA methylomes at base resolution show widespread epigenomic differences. Nature 462: 315-322.

Meissner A, Mikkelsen TS, Gu H, Wernig M, Hanna J, Sivachenko A, Zhang X, Bernstein BE, Nusbaum C, Jaffe DB, et al. 2008. Genomescale DNA methylation maps of pluripotent and differentiated cells. Nature 454: 766-770.

Mikkelsen TS, Ku M, Jaffe DB, Issac B, Lieberman E, Giannoukos G, Alvarez P, Brockman W, Kim TK, Koche RP, et al. 2007. Genome-wide maps of chromatin state in pluripotent and lineage-committed cells. Nature 448: 553-560.

Mohn F, Weber M, Rebhan M, Roloff TC, Richter J, Stadler MB, Bibel M, Schubeler D. 2008. Lineage-specific polycomb targets and de novo DNA methylation define restriction and potential of neuronal progenitors. Mol Cell 30: 755-766.

Ooi SK, Qiu C, Bernstein E, Li K, Jia D, Yang Z, Erdjument-Bromage H, Tempst $\mathrm{P}$, Lin SP, Allis CD, et al. 2007. DNMT3L connects unmethylated lysine 4 of histone $\mathrm{H} 3$ to de novo methylation of DNA. Nature 448: 714-717.

Ooi SK, O'Donnell AH, Bestor TH. 2009. Mammalian cytosine methylation at a glance. J Cell Sci 122: 2787-2791.

Pelizzola M, Koga Y, Urban AE, Krauthammer M, Weissman S, Halaban R, Molinaro AM. 2008. MEDME: an experimental and analytical methodology for the estimation of DNA methylation levels based on microarray derived MeDIP-enrichment. Genome Res 18: 1652-1659.

Schlesinger Y, Straussman R, Keshet I, Farkash S, Hecht M, Zimmerman J, Eden E, Yakhini Z, Ben-Shushan E, Reubinoff BE, et al. 2007. Polycomb-mediated methylation on Lys 27 of histone H3 pre-marks genes for de novo methylation in cancer. Nat Genet 39: 232-236.

Seila AC, Calabrese JM, Levine SS, Yeo GW, Rahl PB, Flynn RA, Young RA, Sharp PA. 2008. Divergent transcription from active promoters. Science 322: 1849-1851.

Song CX, Szulwach KE, Fu Y, Dai Q, Yi C, Li X, Li Y, Chen CH, Zhang W, Jian $X$, et al. 2011. Selective chemical labeling reveals the genome-wide distribution of 5-hydroxymethylcytosine. Nat Biotechnol 29: 68-72.

Szwagierczak A, Bultmann S, Schmidt CS, Spada F, Leonhardt H. 2010. Sensitive enzymatic quantification of 5-hydroxymethylcytosine in genomic DNA. Nucleic Acids Res 38: e181. doi: 10.1093/nar/gkq684.

Tahiliani M, Koh KP, Shen Y, Pastor WA, Bandukwala H, Brudno Y, Agarwal S, Iyer LM, Liu DR, Aravind L, et al. 2009. Conversion of 5-methylcytosine to 5-hydroxymethylcytosine in mammalian DNA by MLL partner TET1. Science 324: 930-935.

Weber M, Hellmann I, Stadler MB, Ramos L, Paabo S, Rebhan M, Schubeler D. 2007. Distribution, silencing potential and evolutionary impact of promoter DNA methylation in the human genome. Nat Genet 39: 457-466.

Wu H, Coskun V, Tao I, Xie W, Ge W, Yoshikawa K, Li E, Zhang Y, Sun YE. 2010. Dnmt3a-dependent nonpromoter DNA methylation facilitates transcription of neurogenic genes. Science 329: 444-448.

Wu H, D'Alessio AC, Ito S, Xia K, Wang Z, Cui K, Zhao K, Sun Y, Zhang Y. 2011. Dual functions of Tetl in transcriptional regulation in mouse embryonic stem cells. Nature doi: 10.1038/nature09934. 


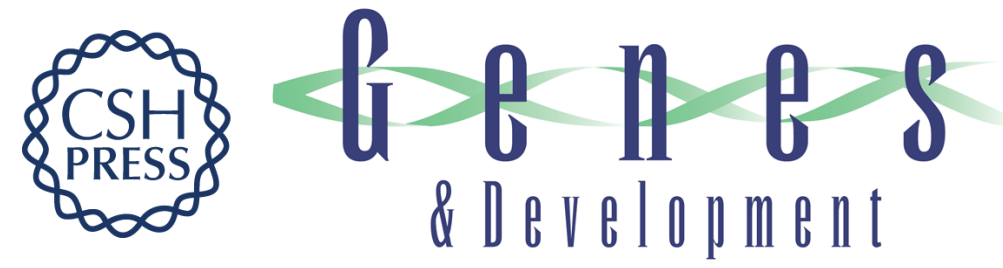

\section{Genome-wide analysis of 5-hydroxymethylcytosine distribution reveals its dual function in transcriptional regulation in mouse embryonic stem cells}

Hao Wu, Ana C. D'Alessio, Shinsuke Ito, et al.

Genes Dev. 2011, 25:

Access the most recent version at doi:10.1101/gad.2036011

Supplemental http://genesdev.cshlp.org/content/suppl/2011/03/30/25.7.679.DC1

Material

References This article cites 25 articles, 6 of which can be accessed free at: http://genesdev.cshlp.org/content/25/7/679.full.html\#ref-list-1

License

Email Alerting Receive free email alerts when new articles cite this article - sign up in the box at the top Service right corner of the article or click here.

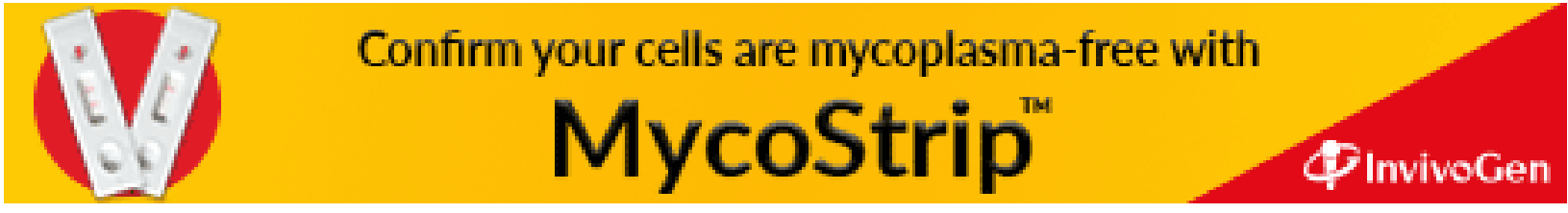

